\title{
Bronchoalveolar Lavage in Occupational Lung Diseases
}

\author{
Carlos Robalo Cordeiro, M.D., Ph.D., 1 Jessica Cemlyn Jones, M.D., ${ }^{1}$ \\ Tiago Alfaro, M.D., ${ }^{1}$ and António Jorge Ferreira, M.D., M.S.C. ${ }^{2}$
}

\section{ABSTRACT}

Occupational lung diseases (OLDs) are related to the exposure and inhalation of organic, inorganic, and synthetic particles, fumes, gases, or infectious agents. From the long list of OLDs this article focuses the discussion on bronchoalveolar lavage (BAL) in parenchymal immunoinflammatory conditions, such as hypersensitivity pneumonitis (HP) and pneumoconiosis.

Several antigens may cause HP, including products of plant or animal origin, aerosolized microorganisms, and organic chemicals. BAL is used not only to assess the pathogenesis of these diseases but also to identify the typical pattern of intense lymphocytic alveolitis, usually with a CD4:CD8 ratio below normal and frequently with the presence of mast cells, plasma cells, and foamy macrophages.

Pneumoconioses are chronic interstitial lung diseases caused by the inhalation of mineral and metallic inorganic particles/dusts in an occupational setting, showing a decreasing prevalence in recent years.

BAL is a useful tool not only to express the complex pathogenic mechanisms of these entities but also in excluding other diagnoses and causes of alveolitis, and to document specific exposures, such as the identification of asbestos bodies (ABs) in asbestosis or the proliferative response of BAL lymphocytes to beryllium in chronic beryllium disease $(\mathrm{CBD})$.

KEYWORDS: Bronchoalveolar lavage, occupational lung diseases, hypersensitivity pneumonitis, pneumoconiosis

The risks of injury and lung disease have been recognized in mining since the 16 th century and were elegantly described at that time by Agrícola.

Currently we are aware that there is an ongoing increase of occupational lung diseases (OLDs) in several developed or developing countries, and that, in Western countries, there is a shift in these diseases from pneumoconiosis to occupational asthma, the current most common work-related respiratory event. ${ }^{1}$
This is closely related to industrial development and the improvement of new biotechnologies, with changes not only in agriculture and basic industries, like mining and metallurgy, reflected in fewer risk populations, better hygiene measures, and less harmful exposure, but also in the widespread use of enzymes, leading to a higher degree of sensitized workers, expressed in an increasing number of allergic occupational diseases. $^{2}$

\footnotetext{
${ }^{1}$ Department of Pulmonology and Allergology, Coimbra University Hospital, Coimbra, Portugal; ${ }^{2}$ Institute of Hygiene and Social Medicine, Coimbra Medical School, Coimbra, Portugal.

Address for correspondence and reprint requests: Carlos Robalo Cordeiro, M.D., Ph.D., Department of Pulmonology and Allergology, Coimbra University Hospital, Praceta Mota Pinto, 3000 Coimbra, Portugal (e-mail: crobalo@mail.telepac.pt).
}

Bronchoalveolar Lavage; Guest Editors, Robert P. Baughman, M.D., Ulrich Costabel, M.D., and Keith C. Meyer, M.D.

Semin Respir Crit Care Med 2007;28:504-513. Copyright (C) 2007 by Thieme Medical Publishers, Inc., 333 Seventh Avenue, New York, NY 10001, USA. Tel: +1(212) 584-4662.

DOI 10.1055/s-2007-991523. ISSN 1069-3424. 
However, in most countries, there are still inadequate data to determine the number of injured workers or those at risk, and the association between exposure to a potentially harmful agent and lung disease is underestimated.

Nevertheless it seems that OLDs are, in terms of frequency, severity, and preventability, the most common work-related illnesses in the United States. ${ }^{3}$

In this context, there were $\sim 22.000$ newly reported occupational respiratory conditions in the United States during the year 2002, and during the same period, it is estimated that nonfatal OLDs were under progression in overall 2.5 per 10.000 fulltime workers.

OLD may develop through exposure and inhalation of organic, inorganic, and synthetic particles, fumes, gases, or infectious agents, under an isolated or multifarious context, in the workplace or even due to a particular hobby. It is essential to confirm or rule out an occupational etiology, not only through a detailed occupational history but also by searching for confounding or related factors, like smoking habits, exposure to other pollutants, and certain hobbies. ${ }^{5}$

These exposures can lead to several conditions, like airways diseases (asthma, occupational bronchitis, and acute inhalation disorders), infectious and malignant conditions, hypersensitivity pneumonitis (HP), and pneumoconiosis, expressed in a long list of clinical entities.

The discussion here focuses on bronchoalveolar lavage (BAL) in OLD parenchymal immunoinflammatory conditions, such as HP and pneumoconiosis.

\section{HYPERSENSITIVITY PNEUMONITIS}

$\mathrm{HP}$, also known as extrinsic allergic alveolitis, is an inflammatory and granulomatous interstitial lung disease caused by intense and/or repeated inhalation of organic dusts, with further sensitization.

Although HP was recognized by Ramazinni, in 1713 , through the report of wheat reapers with this clinical pattern, ${ }^{6}$ the first description of the disease was made by Campbell in 1932, in farmers exposed to moldy hay, with so-called farmer's lung. ${ }^{7}$

Today, there are more than 200 different antigens underlying HP, consisting of products of plant or animal origin, aerosolized microorganisms, and organic chemicals that must have a diameter below 3 to $5 \mu \mathrm{m}$ to be inhaled and reach the lung periphery. ${ }^{8}$

The most frequent antigens are listed in Table 1 and are related to a variety of distinct occupations in different places of the world, from plaster workers exposed to esparto dust in the southeast Iberian

Table 1 Main Causes of Hypersensitivity Pneumonitis

\begin{tabular}{|c|c|c|}
\hline Antigen/Agent & Source & Disease \\
\hline $\begin{array}{l}\text { Thermophilic actinomycetes- } \\
\text { Micropolyspora faeni, } \\
\text { Thermoactinomyces vulgaris, } \\
\text { T. saccharii, T. viridis, T. candidus }\end{array}$ & $\begin{array}{l}\text { Moldy hay, moldy compost, } \\
\text { moldy plant materials, moldy } \\
\text { sugarcane residue }\end{array}$ & $\begin{array}{l}\text { Farmer's lung Ventilation pneumonitis } \\
\text { Bagassosis Mushroom worker's disease }\end{array}$ \\
\hline Avian proteins & Bird droppings/feathers/serum & $\begin{array}{l}\text { Bird-breeder's lung, bird-fancier's lung, } \\
\text { pigeon-breeder's lung }\end{array}$ \\
\hline Rat urinary proteins & Rat urine or serum & $\begin{array}{l}\text { Laboratory worker's hypersensitivity } \\
\text { pneumonitis }\end{array}$ \\
\hline Trichosporon cutaneum & Mold in Japanese homes & Summer-type hypersensitivity pneumonitis \\
\hline Isocyanates & Paints, plastics & Isocyanates hypersensitivity pneumonitis \\
\hline Anhydrides & Plastics & Epoxy-worker's lung \\
\hline Penicillium glabrum (frequentans) & Moldy cork & Suberosis \\
\hline Penicillium casei & Cheese mold & Cheese-washer's lung \\
\hline Aspergillus clavatus & Moldy grains & Malt-worker's lung \\
\hline Cryptostroma corticale & Moldy maple bark & Maple bark-stripper's disease \\
\hline Aureobasidium pullulans & Moldy sequoia dust & Sequoiosis \\
\hline $\begin{array}{l}\text { Amoeba-Naegleria gruberi, } \\
\text { Acanthaemoeba castellani }\end{array}$ & $\begin{array}{l}\text { Contaminated heating, ventilation, } \\
\text { and air conditioning systems } \\
\text { and humidifiers }\end{array}$ & Ventilation pneumonitis \\
\hline Pyrethrum & Insecticides & Insecticide lung \\
\hline Lycoperdon species & Puffballs & Lycoperdonosis \\
\hline Bacillus subtilis proteins & Contaminated wood dust & Woodworker's \\
\hline Bacillus subtilis enzymes & Detergent enzymes & Detergent-worker's lung \\
\hline Mycobacterium avium-intracellulare & Contaminated water & Hot tub lung \\
\hline Aureobasidium & Contaminated water & Sauna-taker's disease \\
\hline
\end{tabular}


Peninsula ${ }^{9}$ to people working in the mushroom crops of Bunashimeji in Japan. ${ }^{10}$

The prevalence of HP is related to several factors, such as the type, intensity, and duration of exposure; the antigen concentration and solubility; particle size; and host susceptibility. It is estimated that, in the population exposed to recognized inciting agents, the prevalence is between 5 and $15 \%,{ }^{11}$ although a larger percentage of individuals may show sensitization, even without lung disease, such as potentially in $\sim 40 \%$ of pigeon breeders. $^{12}$

The antigens, once within the alveolar structures and dependent on the yet described variables, may induce cellular and humoral immune reactions, such as immune complex and cell-mediated immunological disorders. The knowledge acquired about these mechanisms is mostly derived from BAL studies, which are under a clinical or experimental scope.

In this context, BAL may be used to assess the pathogenic pathway of HP, namely, through the evaluation of cytokine levels. Wolff et $\mathrm{al}^{13}$ described how fibronectin and transforming growth factor- $\beta$ are significantly increased in HP patients compared with eosinophilic pneumonia, cryptogenic fibrosing alveolitis, and sarcoidosis individuals, possibly related to a higher intensity of inflammation in HP, and interferon- $\gamma$ is significantly decreased in HP compared with sarcoidosis, probably caused by the Th2 vs Th1 bias in both diseases.

Yet the most typical pattern of BAL in HP is the presence of an intense alveolitis, showing a three- to fivefold increase in cell counts, with a clear predominance of lymphocytes, frequently achieving percentages higher than $50 \%,{ }^{8,14}$ usually with a $\mathrm{CD} 4: \mathrm{CD} 8$ ratio below normal, in which this lymphocytic alveolitis is a major criterion for the diagnosis of HP in the absence of pathological confirmation. ${ }^{15}$

Set against other interstitial lung diseases (ILDs), the presence of mast cells is more frequent in HP; also plasma cells are frequent in HP and in a small number of other clinical entities such as organizing pneumonia, chronic eosinophilic pneumonia, and aspiration pneumonia. ${ }^{14}$ Macrophages often exhibit particular morphological changes, namely, a foamy cytoplasm.

Nonetheless, these BAL findings are dependent on the timing of the last antigen exposure; neutrophils are elevated within 48 hours after acute exposure and values return to normal within a week. On the other hand, lymphocyte levels remain increased a long time after removal of the inciting antigen, sometimes years, but in lower percentages compared with patients still exposed. When progression leads to fibrosis, neutrophils may again be increasingly present in HP and CD4:CD8 ratio may show mild elevation. ${ }^{8,11}$

The different lymphocytic phenotyping was reported by Ando et $\mathrm{al}^{16}$ in 271 patients with summertype HP (CD4:CD8 $=0.6 \pm 0.1)$ compared with 22 farmer's lung HP ( $4.4 \pm 0.7)$. This different CD4:CD8 ratio, with important implications in the immunopathogenesis of HP, may depend on several factors, such as (1) the type and dose of inhaled antigen (being intermittent exposures to Micropolyspora faeni eventually related with the high levels found in farmer's lung and more continuous exposures to low concentrations of Trichosporum cutaneum reflected in the diminished numbers of summer-type HP); (2) the characteristics of granuloma (smaller and immature in summer-type HP); (3) the staging of disease, as previously stressed, and the therapy received; (4) the existence of other inhalants (eventually present in farmer's lung patients); and (5) smoking habits (higher CD4:CD8 ratio in farmer's lung smokers vs nonsmokers). Interestingly, more HP cases occur in nonsmokers, which is likely due to the immunosuppressive effects of tobacco, reflected in a decrease in the production of specific antibodies to the causative antigens. ${ }^{8}$

Concerning neutrophils, Pardo et $\mathrm{a}^{17}$ showed a positive correlation between the percentage of lung tissue polymorphonuclear leukocytes (PMN) and the percentage of lung fibrosis in $15 \mathrm{HP}$ patients, but there was no correlation between BAL and lung neutrophils.

Some investigators suggested correlations between the number of neutrophils in BAL and either the severity or the response to therapy or both in idiopathic pulmonary fibrosis (IPF) ${ }^{18}$ or the activity and prognosis of sarcoidosis ${ }^{19}$ or even with the fibrotic evolution in HP. ${ }^{17,20}$ However, these findings were not confirmed by other studies. ${ }^{14}$ The importance of BAL $\mathrm{PMN}$ as a marker of activity of disease or disease evolution requires further investigation.

However, the most important diagnostic information obtained from BAL cellularity is that normal values rule out $\mathrm{HP}$, making $\mathrm{BAL}$ a sensitive tool in the differential diagnosis with other ILDs. ${ }^{5,8,11,14,15,21}$ In this context, Drent et al developed a software program, using patients (gender and age) and BAL (percentage of recovery, total cellularity, and quantification of macrophagic, lymphocytic, and neutrophilic populations) data. A logistic regression mathematical analysis is applied to these data and used as a method of high positive predictive value to differentiate the most prevalent ILD disorders: HP, sarcoidosis, and idiopathic pulmonary fibrosis. ${ }^{22,23}$

Nevertheless, there may be considerable overlap with BAL data when considering HP and other entities, namely, nonspecific interstitial pneumonitis (NSIP) and the newly described airway-centered interstitial fibrosis (ACIF) pattern. ${ }^{24,25}$

Moreover, BAL does not differentiate between healthy, sensitized individuals-the so-called subclinical alveolitis (SA) - and HP patients, only allowing the exclusion of nonsensitized individuals. 
Table 2 Bronchoalveolar Lavage Data on Hypersensitivity Pneumonitis-Pulmonology Research Centre

\begin{tabular}{llllll}
\hline Total Cells $\times \mathbf{1 0}^{\mathbf{4}}$ & Macrophages \% & Lymphocytes \% & Neutrophils \% & Eosinophils \% & CD4:CD8 \\
\hline $33.7 \pm 16.3$ & $59 \pm 29.6$ & $35 \pm 28.9$ & $4 \pm 5$ & $2 \pm 2.9$ & $0.9 \pm 0.5$ \\
\hline
\end{tabular}

Numerous studies have been performed in this field, in the Research Centre of Pulmonology-University of Coimbra (CPUC), on SA in several occupational and nonoccupational diseases, as in pigeon breeders, patients treated with amiodarone, workers exposed to asbestos fibers and crystalline silica, and in cutaneous sarcoidosis, connective tissue diseases, and patients with human immunodeficiency virus (HIV) infection. ${ }^{26-31}$

Although uncovering these BAL changes in individuals without respiratory symptoms, with a normal chest $\mathrm{x}$-ray and normal lung function, could be of obvious interest for the clarification of pathogenic mechanisms and for supporting the cessation of exposure to the likely related agents (antigens, medications, or others), the significance of SA is still discussed, as a local expression of systemic diseases or as an isolated pulmonary involvement. The prognostic implication remains obscure because additional cellular and mediator data and more comprehensive longitudinal studies are needed. ${ }^{32,33}$

In a retrospective analysis of the last 20 consecutive patients with HP with different causes submitted to BAL in the CPUC, the authors confirmed the existence of a lymphocytic alveolitis with diminished CD4:CD8 values (Table 2).

From this retrospective study, the authors single out a patient with one of the most prevalent HPs in Portugal; a 45-year-old nonsmoking businessman who was referred to the pulmonology outpatient clinic because of a 5-month history of persistent cough productive of sputum, exertional dyspnea, wheezing, and fatigue. $\mathrm{He}$ bred chickens, pigeons, turtle-doves, and canaries.

Chest $\mathrm{x}$-ray revealed a bilateral reticulonodular pattern, and high-resolution computed tomography (HRCT) showed ground-glass attenuation (Fig. 1).
Lung function indicated a restrictive ventilatory defect with a forced vital capacity (FVC) of $60.07 \%$, forced expiratory volume in 1 second (FEV1) of 62.6\%, and $\mathrm{FEV} 1 / \mathrm{FVC}$ of $86.7 \%$, with severe reduction of diffusion capacity "transfer lung capacity (TLCO)" of $37.8 \%$

BAL findings included a significant increase in total cell count $\left(74 \times 10^{4}\right.$ cells $\left./ \mathrm{mL}\right)$, with lymphocytic predominance ( $80 \%$ of total cells), showing also the presence of plasma cells, mast cells, and foamy macrophages (Figs. 2 and 3).

Laboratory findings included precipitating antibodies "immunoglobulin $\mathrm{G}(\mathrm{IgG})$ " for pigeon feathers, droppings, and serum and negative results for chickens, turtle-doves, and canaries.

This suggestive clinical picture of HP related to pigeon breeder's disease, also reinforced by the interstitial infiltrate of lymphocytes, plasma cells, neutrophils, and eosinophils found on histology obtained from a transbronchial biopsy (Fig. 4), strongly suggest allergen contact avoidance.

Indeed, after removal of the birds from the patient's home and a treatment with oral steroids ( $1 \mathrm{mg} / \mathrm{kg} / \mathrm{d}$ of prednisone followed by gradual taper), there was significant clinical, radiological, and functional improvement, denoted by the absence of symptoms after 4 months and also disclosed in Fig. 5 and Table 3.

Portugal is the largest cork-producing country in the world, with more than 1000 factories, employing about 15,000 workers; consequently, suberosis is particularly prevalent. Suberosis together with bird fancier's disease (BFD), represent two of the most frequent HP etiologies in this country. Suberosis is caused by the repeated inhalation of Penicillium glabrum (formerly known as Penicillium frequentans) that contaminates
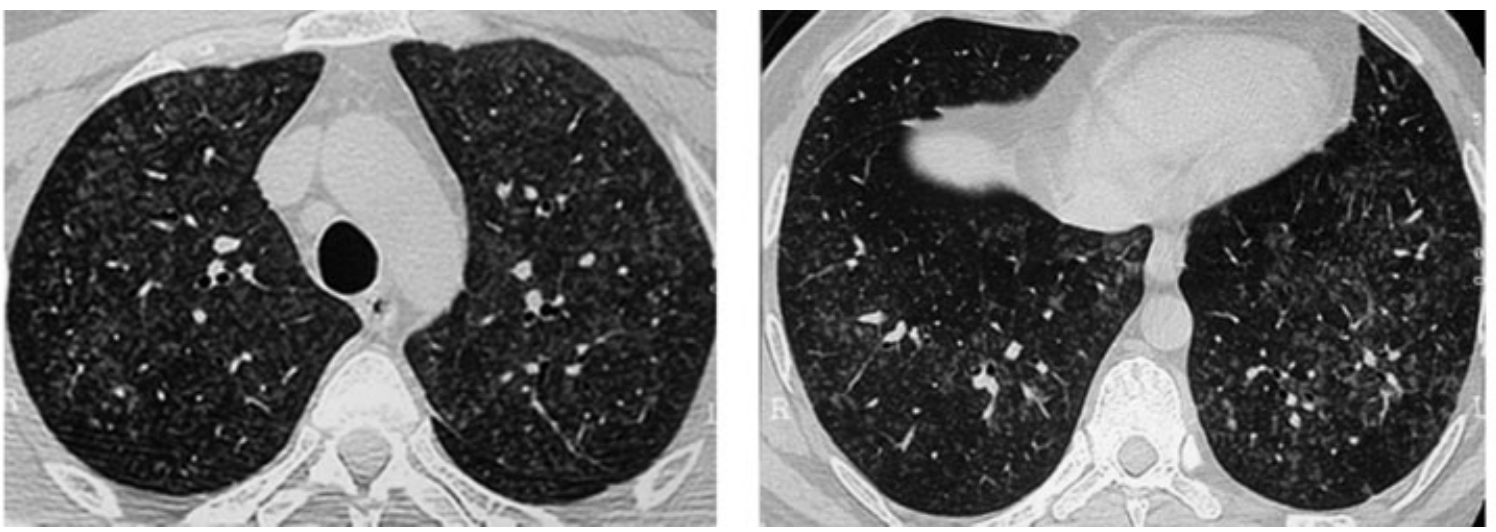

Figure 1 High-resolution computed tomography with ground-glass attenuation in (A) upper and (B) lower lobes. 


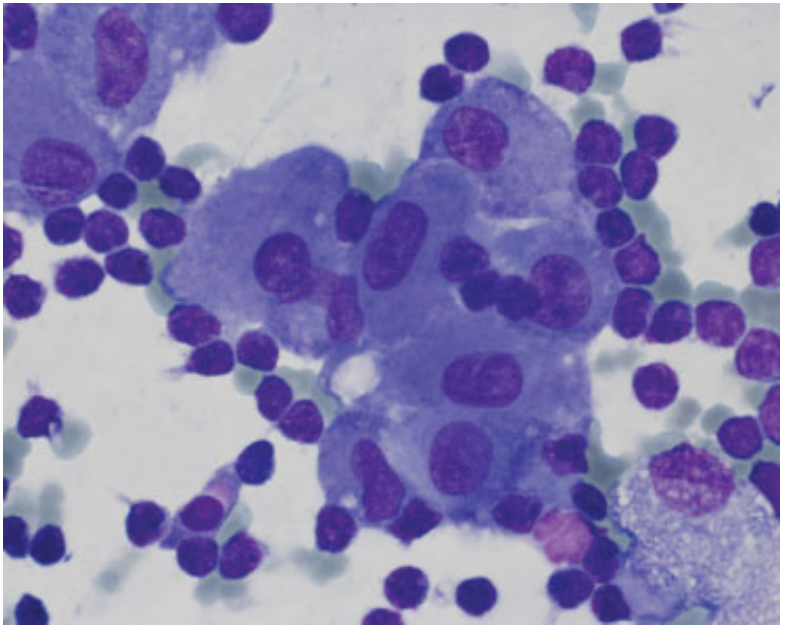

Figure 2 Lymphocytic alveolitis, activated macrophages (one showing foamy cytoplasmic alterations) and presence of a plasma cell. May-Grünwald Giemsa (MGG) × 100 .

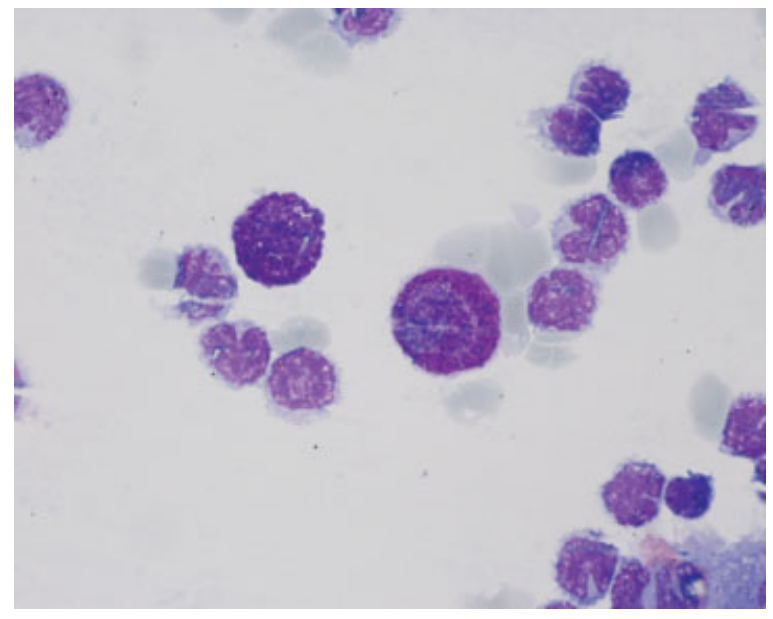

Figure 3 Presence of two mast cells in a slide with lymphocytic predominance. MGG $\times 100$.

A

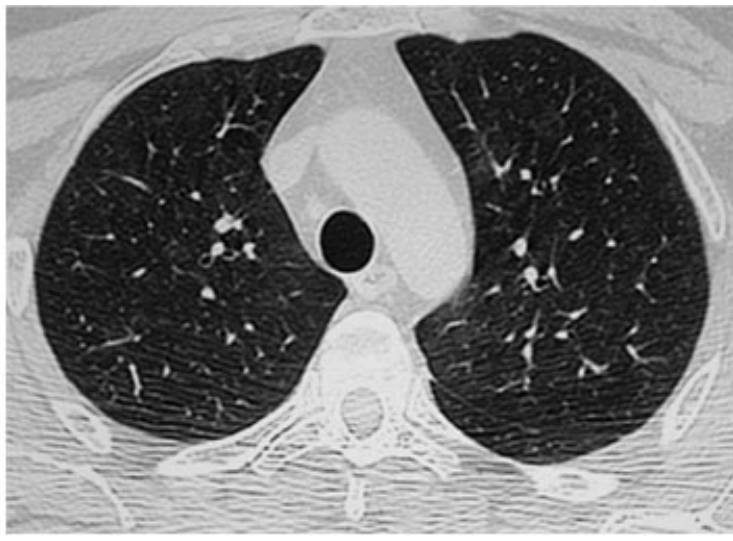

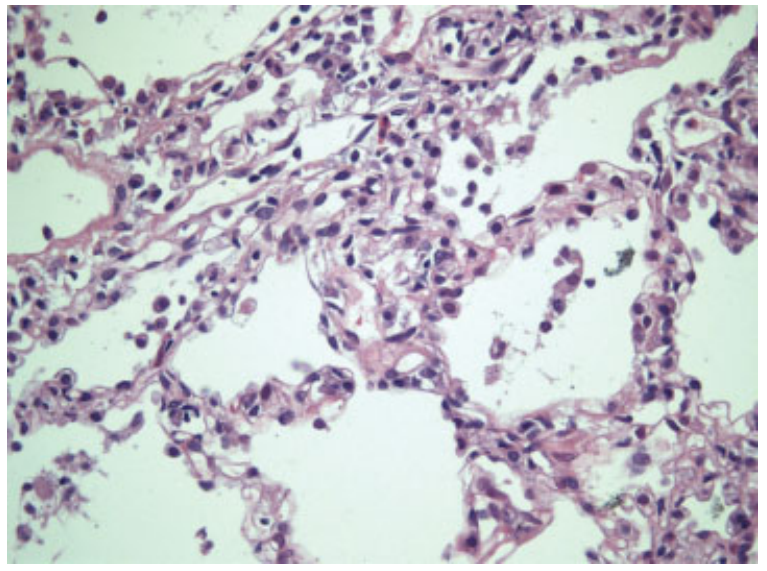

Figure 4 Transbronchial biopsy showing interstitial inflammatory infiltrate.

cork during its industrial processing, and it is estimated that the prevalence of this disease among cork workers is between 9 and $19 \% .^{34}$

A large cohort of patients with these diseases (81 with suberosis and 32 with BFD) was recently described, allowing clinical, functional, radiological, and BAL patterns to be compared in both populations. ${ }^{35}$

Besides the findings of more acute forms and more severe restrictive defects in patients with $\mathrm{BFD}$, BAL revealed more intense alveolitis in BFD $\left(90 \times 10^{4}\right.$ cells $/ \mathrm{mL}$ vs $66 \times 10^{4}$ cells $/ \mathrm{mL}$ in suberosis), with more lymphocytes, in absolute and also relative numbers (61.7\% in BFD vs $58.8 \%$ in suberosis), and CD4:CD8 ratio was significantly more decreased in suberosis $(0.47$ vs 1.1 in BFD).

Comparing patients no longer exposed to those still exposed, the only difference was a diminished percentage of $\mathrm{CD} 8+$ cells in the case of suberosis individuals where the agent was withdrawn $(49.3 \%$ vs $55.5 \%)$.

This study thus confirms the interest of BAL data by showing the existence of different immune and inflammatory responses, even in disorders with pathophysiological similarities.

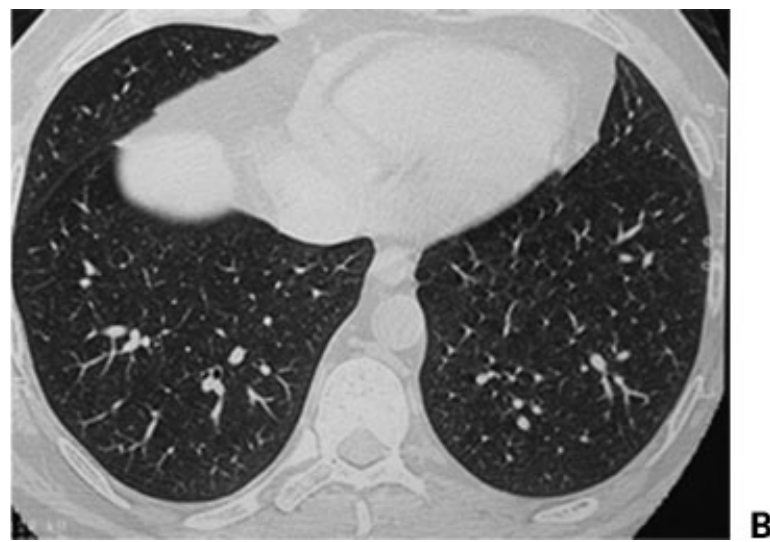

Figure 5 Normal high-resolution computed tomography-(A) upper and (B) lower lobes. 
Table 3 Pulmonary Function Tests of Hypersensitivity Pneumonitis Patient: Follow-Up and Evaluation

\begin{tabular}{llcl}
\hline Variable & $\begin{array}{l}\text { Presentation } \\
(\%)\end{array}$ & $\begin{array}{l}\text { 4 Months } \\
\text { Later (\%) }\end{array}$ & $\begin{array}{l}\text { 10 Months } \\
\text { Later (\%) }\end{array}$ \\
\hline FVC & 60.07 & 98.41 & 106.8 \\
FEV1 & 62.62 & 102.3 & 105.4 \\
FEV1/TVC & 86.72 & 86.42 & 81.94 \\
TLC & 67.01 & 85.34 & 77.40 \\
TLCO (SB) & 37.88 & 53.69 & 83.96 \\
\hline
\end{tabular}

FEV1, forced expiratory volume in 1 second; FVC, forced vital capacity; SB, single breath; TLC, total lung capacity; TLCO, transfer lung capacity.

\section{PNEUMOCONIOSES}

Pneumoconioses are chronic ILDs caused by the inhalation of mineral and metallic inorganic particles/dusts in an occupational setting. The changing pattern of OLD is reflected, in developed countries, in a decrease in the prevalence of pneumoconioses and even in a better outcome of these entities, which is related to a tighter control and reduction of hazardous exposures, earlier diagnosis of the diseases, and the replacement of known aggressive industrial agents. ${ }^{36}$ Nevertheless, there remain various occupations that may result in exposure to several causal agents of pneumoconioses, ${ }^{37-40}$ summarized in Table 4.

The inhalation of agents such as crystalline silica may evoke lung reactive processes and injuries leading to pulmonary fibrosis. This depends on several factors, including the duration of exposure, the concentration of particles in the environment, the dimensions of the particles (particles reach the alveoli only if the particle diameter is less than 5 to $3 \mu \mathrm{m}$ ) and their morphological and physicochemical surface characteristics. Host factors such as individual worker susceptibility should also be considered.

The pathogenic mechanisms are complex, initially sustained by macrophagic and natural killer cell inter- vention, after opsonization of particles by surfactant and other substances. These changes may be expressed on BAL (and also on tissue samples) by alveolitis of lymphocytic predominance and sometimes also with a neutrophilic or mixed pattern. Usually, there is preferential activation of CD4 or CD8 lymphocytes and TH1/TH2 differentiation inducing progression to a granulomatous reaction or to fibrosis, with activation of interleukins$1,4,6,8,10,12$, and 13 , tumor necrosis factor (TNF)- $\alpha$, matrix metalloprotease (MMP)-1, tissue inhibitor of metalloprotease (TIMP)-1, intercellular adhesion molecule (ICAM) -1 , transforming growth factor (TGF)- $\beta$, epidermal growth factor (EGF), insulin growth factor (IGF), platelet-derived growth factor (PDGF), among others. ${ }^{41,42}$

In silicosis (the most prevalent chronic occupational disease in the world, resulting from inhalation of crystalline or free silica, usually in the form of quartz), it is possible to find a lymphocytic SA on initial exposure. However, alveolitis usually exhibits a mixed lymphocytic/granulocytic pattern, macrophages may be increased, and the CD4:CD8 ratio is decreased.

$\mathrm{BAL}$ is also important in excluding other diagnoses and causes of alveolitis, and to document specific dust exposures.

In this context the authors stress two entities where BAL findings are particularly useful, asbestosis and berylliosis.

Exposure to asbestos gives rise to pulmonary fibrosis (asbestosis), lung cancer, and pleural diseases, which may be benign (effusion, fibrosis, plaques) or malignant (mesothelioma).

Asbestos fibers are silicate fibers of different lengths and widths, from two main families: serpentines (chrysotile) and amphiboles (crocidolite, the most frequent, and also amosite, tremolite, anthophyllite, and actinolite). Chrysotile represents between 90 and 95\%

Table 4 Main Causes of Pneumoconioses

\begin{tabular}{|c|c|}
\hline Activities & Agent \\
\hline $\begin{array}{l}\text { Ceramic and pottery plants, sandblasting, mining industry, quarries, tunneling, foundry work, } \\
\text { coal working and extraction, stone cutting, cement production, glazing, vitreous enameling }\end{array}$ & Free silica dust \\
\hline $\begin{array}{l}\text { Thermal and acoustic insulation, mining, shipyard activities, automotive industry, textile industry, } \\
\text { production of friction materials }\end{array}$ & Asbestos \\
\hline $\begin{array}{l}\text { Mining industry, quarries, rubber and paper production industry, ceramic and } \\
\text { pottery plants, cosmetics }\end{array}$ & Silicates and talc \\
\hline Mining, smelting, grinding steel, polishing, arc welding & Iron \\
\hline Diamond polishing, electroplating & Cobalt \\
\hline China, fine earthenware, and pottery product manufacturing & Kaolin \\
\hline $\begin{array}{l}\text { Fluorescent and neon lamp industries, aircraft engines, guidance systems and brakes, } \\
\text { x-ray tube windows, turbine reactor blades, dental castings and prostheses, electrical } \\
\text { and electronic components, high-tech ceramics }\end{array}$ & Beryllium \\
\hline Hard metal tools manufacturing & Hard metal \\
\hline Explosives workers, blasters, aluminum powder workers & Aluminum \\
\hline
\end{tabular}


of the world production, namely, in Canada, Alaska, and the Russian Federation. Nevertheless, crocidolite has been identified as a more potent fibrogenic agent, so pulmonary fibrosis is more frequent in processing than in the mining industry. Moreover, intermittent exposures, for example, in shipyards, are related to a higher prevalence of pleural changes, whereas more continuous and cumulative exposures are related to parenchymal fibrosis. ${ }^{36,42,43}$

BAL is a useful tool in asbestosis, not only to assess the common moderate lymphocytic (and/or neutrophilic) alveolitis, higher in the initial phases (eventually as an SA), lower in more advanced disease, and usually associated with augmented CD4:CD8 ratio, but essentially to identify and quantify the asbestos fibers.

It is assumed that the number of asbestos bodies $(\mathrm{ABs})$ found in BAL reflects concentration of these bodies in the lung. ${ }^{44}$ More controversial is the choice of method to identify the asbestos and the significance of the quantitative counting of fibers. $\mathrm{ABs}$ can be seen directly on BAL slides but quantitative demonstration after filtration with the $\mathrm{AB}$ Millipore filtration system (Millipore, Billerica, MA) seems to be more sensitive, namely, when the level is low ${ }^{14,45}$; this filtration followed by light microscopy study of $20 \mathrm{~mL}$ of BAL is the method recommended by a working group from the European Respiratory Society (ERS). ${ }^{46}$ Also, it is important to recognize and differentiate true $\mathrm{ABs}$, with a thinner segmented rod, from the thicker pseudobody, with irregularities in its central fiber. On the other hand, $\mathrm{ABs}$ in $\mathrm{BAL}$ are frequently coated with proteic and iron material and are easily identified through light microscopy, whereas the uncoated fibers are only detected by electron microscopy.

In a recent paper, Romeo et $\mathrm{al}^{47}$ compared the counting of ABs in BAL using a phase contrast microscope with the fiber concentration defined by transmission electron microscopy, in 193 asbestos-exposed workers and 84 nonexposed individuals. Electron microscopy revealed positive fibers in all the exposed individuals, whereas phase contrast microscopy detected $A B$ s in only $75.1 \%$ of this population.

Nevertheless, BAL is a reliable, early, and sustained marker of asbestos exposure. The presence of $\mathrm{ABs}$ in BAL is associated with a higher prevalence of respiratory symptoms, reduced pulmonary function, and parenchymal changes. ${ }^{45}$ The correlation between BAL and lung tissue has been presented either as one $\mathrm{AB} / \mathrm{mL}$ of BAL reflecting 100 to $10.000 \mathrm{ABs} / \mathrm{cm}^{3}$ in lung, ${ }^{48}$ or $\sim 1000$ to $3000 \mathrm{ABs} / \mathrm{gr}$ of dry tissue. ${ }^{49}$

This concentration (more than one $\mathrm{AB} / \mathrm{mL}$ of BAL or per $10^{6}$ cells) is considered significant evidence for asbestos exposure ${ }^{49-51}$ with the filtration technique, with sensitivity and specificity of $89 \% .{ }^{52}$ However, Costabel pointed out several more than $0.5 \mathrm{AB} / \mathrm{mL}$ of $\mathrm{BAL}$ as indicative of above-average exposure. ${ }^{14} \mathrm{De}$
Vuyst et $\mathrm{al}^{50}$ reported, in a large population, that $90 \%$ of asbestosis cases had $\geq 5 \mathrm{AB} / \mathrm{mL}$.

However, very high levels of concentration in BAL are now less frequent because the use of asbestos is decreasing in most countries, namely, since the mid1970s, after several regulations of exposure levels and prohibition of use were implemented. This was associated with changing patterns of exposure, from primary asbestos workers to those exposed to materials in buildings and industrial sites. ${ }^{52}$

In the case of the World Trade Center (WTC), $\sim 5000$ tons of asbestos were used for fireproofing in the construction of the towers. In this context, Rom et $\mathrm{al}^{53}$ describe a clinical case of a New York City firefighter exposed to high concentrations of WTC dust for 2 weeks during the September 2001 crisis. Acute eosinophilia was noted as a rare consequence of acute high dust exposure. Besides fly ash and degraded glass, mineralogic analysis of BAL showed 305 uncoated fibers of asbestos per $10^{6}$ cells using electron microscopy, with the absence of coated $\mathrm{AB}$ reflecting the recent acute exposure.

Negative BAL findings do not exclude increased $\mathrm{AB}$ parenchymal content, namely, when there is a mild $\mathrm{AB}$ count in lung tissue. Detection of $\mathrm{ABs}$ in the lung remains the "gold standard" for asbestos exposure. Nonetheless, the search for noninvasive procedures is mandatory, and even induced sputum (IS) is being used in this field.

However, IS seems to be much less sensitive than BAL and useful mainly in the setting of high levels of asbestos exposure. ${ }^{54-56}$ To increase sensitivity, several samples should be obtained from each worker. ${ }^{57}$

Although Capellaro et $\mathrm{al}^{58}$ found agreement of $\mathrm{AB}$ detection between BAL and IS in only $56.8 \%$ of their clinical cases, IS may be a complementary tool to BAL (or even substitutive in the case of contraindication to fiberoptic bronchoscopy), not only in asbestosis, but also in the evaluation of other pneumoconiosis patients (silica and hard metal workers). Fireman et $\mathrm{al}^{59}$ found similar quantitative and qualitative results in the number and chemical analysis of particles obtained by BAL or IS. Thus IS could be useful as a biological monitoring method in periodic health examinations of healthy workers exposed to hazardous dusts and could be performed even in the workplace. ${ }^{56}$

The use of beryllium in industry began in the 1930s and is ongoing, although the number of workers exposed to this metal worldwide is not known.

The chronic beryllium disease (CBD), also known as berylliosis, is a granulomatous disease that has been reported in the United States, Canada, the United Kingdom, Germany, Poland, Israel, Japan, and South Korea. CBD affects $\sim 1$ to $3 \%$ of exposed workers and is clinically, radiologically, and histologically indistinguishable from sarcoidosis. 14,60 
Table 5 Bronchoalveolar Lavage Data on Pneumoconioses-Pulmonology Research Centre

\begin{tabular}{llllll}
\hline Total Cells $\times \mathbf{1 0}^{\mathbf{4}}$ & Macrophages \% & Lymphocytes \% & Neutrophils \% & Eosinophils \% & CD4:CD8 \\
\hline $20.2 \pm 12.3$ & $68.2 \pm 22$ & $22 \pm 12.6$ & $12.8 \pm 15.2$ & $0.2 \pm 0.6$ & $1 \pm 0.9$ \\
\hline
\end{tabular}

BAL is a useful tool not only to clarify the immunopathogenesis of disease-a CD4 $\mathrm{T}$ cell profile with predominant TH1 differentiation eventually regulated by particular human leukocyte antigen (HLA)DPB1 alleles ${ }^{61}$ - but also in a diagnostic context, through the proliferative response of BAL lymphocytes to beryllium.

This lymphocyte transformation test, quantifying the proliferation of lymphocytes incubated with beryllium salts, is always positive in $\mathrm{CBD}$ patients if $\mathrm{BAL}$ lymphocytes are used, but positive in only $50 \%$ of cases if these cells are from the peripheral blood. ${ }^{62}$ Thus BAL is the most sensitive tool to identify the disease. In a retrospective analysis of the last 20 consecutive patients with pneumoconioses with different etiologies submitted to BAL in the CPUC (results on Table 5), the authors found a less intense alveolitis compared with HP patients (Table 2) with a mixed lymphocytic/granulocytic alveolitis.

From the foregoing retrospective study a particular clinical case has been singled out that presents similar radiological findings to the patient mentioned in the case discussed earlier in which only ground-glass attenuation was shown, although it was less severe in expression and once again BAL was crucial for diagnosis.

A 64-year-old male patient, nonsmoker, who had worked in France for 9 years in contact with asbestos in a

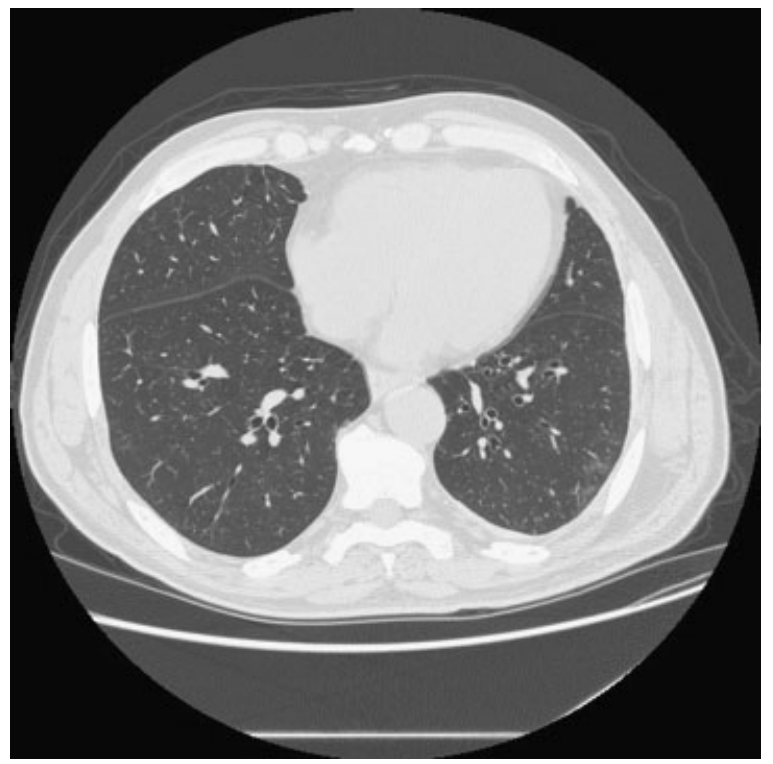

Figure 6 High-resolution computed tomographic scan showing only minor ground-glass attenuation, in the left inferior lobe, on a subpleural localization. factory of thermal isolation materials, presented with complaints of progressive dyspnea and fatigue.

Lung function showed a restrictive ventilatory defect $(\mathrm{FVC}=68.4 \%)$, with reduced diffusion capacity $(\mathrm{TLCO}=65.2 \%)$.

HRCT scan revealed a ground-glass pattern, namely, in the inferior lobes (Fig. 6).

BAL showed the existence of alveolitis (cellularity of $34.8 \times 10^{4} / \mathrm{mL}$ ) with $82.4 \%$ of macrophages, $16.3 \%$ lymphocytes, $0.8 \%$ eosinophils, and $0.5 \%$ neutrophils, and it was possible to identify ABs, in both the suspension (Fig. 7) and intercellularly, with the presence of a fiber phagocytosed by an activated macrophage (Fig. 8), as well as several ABs of $1.6 / \mathrm{mL}$ of BAL.

This clinical case illustrates a lung disorder related to occupation with clinical and functional repercussions and minor alveolar and radiological expression related to working with asbestos. To confirm

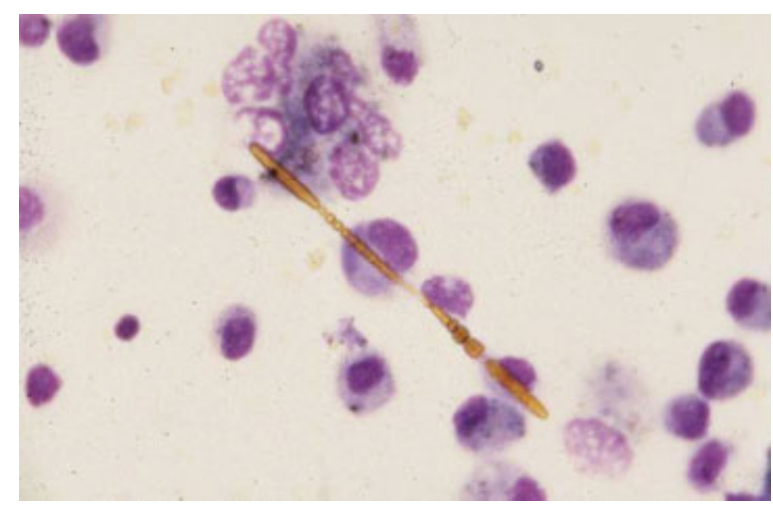

Figure 7 Asbestos fiber in bronchoalveolar lavage. MGG $\times 100$.

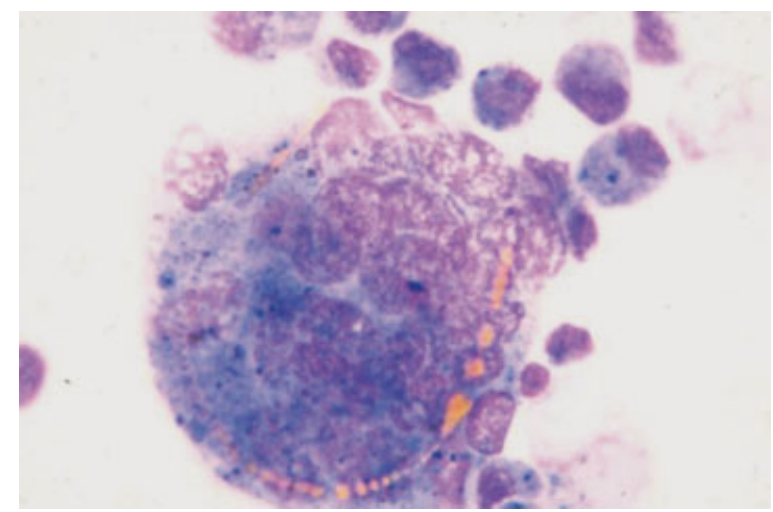

Figure 8 Bronchoalveolar lavage slide showing an asbestos fiber phagocytosed by macrophage. MGG $\times 100$. 
diagnosis, the identification and quantification of the $\mathrm{ABs}$ in BAL fluid were essential.

\section{PERSPECTIVES}

Therapeutic lavage is used in alveolar proteinosis and also, with smaller volumes, in some suppurative disorders.

Since Zhang et $\mathrm{al}^{63}$ reported a delay in the development of disease in rats exposed to silica and submitted to this technique, whole lung lavage has a plausible role to remove inhaled particles in early stages of OLDs.

\section{REFERENCES}

1. Ross DJ, Keynes HL, McDonald JC. SWORD'97: surveillance of work-related and occupational respiratory disease in UK. Occup Med 1998;48:481-485

2. Heederik D. Epidemiology of occupational respiratory diseases and risk factors. In: Annesi-Maesano I, Gulsvik A, Viegi G, eds. Respiratory Epidemiology in Europe. European Respiratory Monograph; 2000;5429-447

3. National Institute for Occupational Safety and Health. Work-Related Lung Diseases Surveillance Report. December 2002

4. U.S. Department of LaborBureau of Labor Statistics. Workplace Injuries and Illnesses in 2002. December 2003

5. Mapp CE. Introduction. In: Mapp CE, ed. Occupational Lung Disorders. European Respiratory Monograph; 1999; 4355

6. Pozzi E. Extrinsic allergic alveolitis (hypersensitivity pneumonitis). In: Grassi C, Brambella C, Costabel U, Stockley RA, Naeije R, Rodriguez-Roisin R, eds. Pulmonary Diseases. London: McGraw-Hill International (UK) Ltd; 1999:289-294

7. Campbell JM. Acute symptoms following work with hay. BMJ 1932;2:1143-1151

8. Mohr LC. Hypersensitivity pneumonitis. Curr Opin Pulm Med 2004;10:401-411

9. Flandes J, Heili S, Seco JG, Sabillon O, Fernández I, Ortega A. Hypersensitivity pneumonitis caused by esparto dust in a young plaster worker: a case report and review of the literature. Respiration 2004;71:421-423

10. Tsushima K, Fujimoto K, Yoshikawa S, Kawakami S, Koizumi T, Kubo K. Hypersensitivity pneumonitis due to Bunashimeji mushrooms in the mushroom industry. Int Arch Allergy Immunol 2005;137:241-248

11. Patel AM, Ryu JH, Reed CE. Hypersensitivity pneumonitis: current concepts and future questions. J Allergy Clin Immunol 2001;108:661-670

12. Fink JN, Schlueter DP, Sosman AJ, et al. Clinical survey of pigeon breeders. Chest 1972;62:277-281

13. Wolff H, Teppo AM, Mutanen P, et al. Studies of cytokine levels in bronchoalveolar fluid lavage from patients with interstitial lung diseases. Scand J Clin Lab Invest 2003;63: 27-36

14. Costabel U. Atlas of Bronchoalveolar Lavage. London: Chapman \& Hall Medical; 1998

15. The BAL Cooperative Group Steering Committee. Bronchoalveolar lavage constituents in healthy individuals, idiopathic pulmonary fibrosis, and selected comparison groups. Am Rev Respir Dis 1990;141:S169-S202

16. Ando M, Konishi K, Yoneda R, Tamura M. Difference in the phenotypes of bronchoalveolar lavage lymphocytes in patients with summer-type hypersensitivity pneumonitis, farmer's lung, ventilation pneumonitis, and bird fancier's lung: report of a nationwide epidemiologic study in Japan. J Allergy Clin Immunol 1991;87:1002-1009

17. Pardo A, Barrios R, Gaxiola M, et al. Increase of lung neutrophils in hypersensitivity pneumonitis is associated with lung fibrosis. Am J Respir Crit Care Med 2000;161:16981704

18. Turner-Warwick M, Haslam PL. The value of serial bronchoalveolar lavages in assessing the clinical progress of patients with cryptogenic fibrosing alveolitis. Am Rev Respir Dis $1987 ; 135: 26-34$

19. Drent M, Jacobs JA, de Vries J, et al. Does the cellular bronchoalveolar lavage fluid profile reflect the severity of sarcoidosis? Eur Respir J 1999;13:1338-1344

20. Perez-Padilla R, Salas J, Chapela R, et al. Mortality in Mexican patients with chronic pigeon breeder's lung compared with those with usual interstitial pneumonia. Am Rev Respir Dis 1993;148:49-53

21. Robalo Cordeiro C, Freitas S, Rodrigues B, et al. Diagnosis of respiratory bronchiolitis associated lung disease. Monaldi Arch Chest Dis 2006;65:96-101

22. Drent M, van Nierop MAMF, Gerritsen FA, Wouters EFM, Mulder PGH. A computer program using BALF-analysis results as a diagnostic tool in interstitial lung diseases. Am J Respir Crit Care Med 1996;153:736-741

23. Drent M, Jacobs JA, Cobben NAM, Costabel U, Wouters EFM, Mulder PGH. Computer program supporting the diagnostic accuracy of cellular BALF analysis: a new release. Respir Med 2001;95:781-786

24. Drent M, Du Bois R, Poletti V. Recent advances in the diagnosis and management of nonspecific interstitial pneumonia. Curr Opin Pulm Med 2003;9:411-417

25. Cordeiro CR. Airway involvement in interstitial lung disease. Curr Opin Pulm Med 2006;12:337-341

26. Segorbe Luís AJ, Abreu AF, Cordeiro CR, et al. Subclinical alveolitis in pigeon breeders. Sarcoidosis 1989;6(Suppl1): 61

27. Freitas MS, Pêgo A, Cordeiro CR, et al. Subclinical alveolitis in amiodarone treated patients. Eur Resp Rev 1992;2: 224

28. Baganha MF, Abreu F, Teixeira ML, et al. Subclinical alveolitis in asbestos exposed workers. Eur Respir Rev 1991;1:7

29. Robalo Cordeiro AJA, Leite ACP, Lima MA, et al. Early lung involvement in silica exposed workers. Eur Respir J 1992;5(Suppl 15):521

30. Cordeiro CR, Mesquita L, Teixeira L, Cardoso Oliveira L. Subclinical alveolitis in extrathoracic granulomatous disease. Sarcoidosis 2001;18:34-35

31. Baganha MF, Marques MAT, Leite I, et al. Subclinical alveolitis in asymptomatic individuals infected by HIV. Eur Respir J 1994;7(Suppl 18):121

32. Laviolette M, Cormier Y, Loiseau A, Soler P, Leblanc P, Hance AJ. Bronchoalveolar mast cells in normal farmers and subjects with farmer's lung. Am Rev Respir Dis 1991;144: 855-860

33. Robalo Cordeiro AJA. Alveolites subclínicas: perspectiva imunológica. Rev Port Imunoalerg 1992;3:73-85 
34. Ávila R, Lacey J. The role of Penicillium frequentans in suberosis: respiratory disease in cork workers. Clin Allergy 1974;4:109

35. Morais A, Winck JC, Delgado L, et al. Suberose e doença dos criadores de aves: estudo comparativo do perfil radiológico funcional e do lavado broncoalveolar. Rev Port Pneumol 2004;10:63-75

36. Chan-Yeung M, Dimichi-Ward H. Natural history of occupational lung disease. In: Mapp CE, ed. Occupational Lung Disorders. European Respiratory Monograph; 1999; 4:446-463

37. Kayacan O, Beder S, Karnak D. Cellular profile of bronchoalveolar lavage fluid in Turkish miners. Postgrad Med J 2003;79:527-530

38. Rottoli P, Bargagli E, Perari MG, Cintorino M, Romeo R. Gardening in greenhouses as a risk factor for silicosis. Respiration 2003;70:221-223

39. Antonini JM, Taylor MD, Zimmer AT, Roberts JR. Pulmonary responses to welding fumes: role of metal constituents. J Toxicol Environ Health, Part A 2003;67: 233-249

40. Robalo Cordeiro AJA, Baganha MF, Carmo JGA, Gaspar E, Lima MAM, Rosa MAS. Le lavage broncho-alvéolaire chez des mineurs d'uranium. Rev Fr Mal Respir 1981;9:241-256

41. Barbarin V, Xing Z, Delos M, Lison D, Huaux F. Pulmonary overexpression of IL-10 augments lung fibrosis and TH2 responses induced by silica particles. Am J Physiol Lung Cell Mol Physiol 2005;288:L841-L848

42. Robalo Cordeiro AJA, Cordeiro CR. Exposição pulmonar profissional: pneumoconioses. In: Marques Gomes MJ, Sotto-Mayor R, eds. Tratado de Pneumologia. Portugal: Permanyer; 2003;2:1407-1419

43. Bégin R. Asbestos-related diseases. In: Mapp CE, ed. Occupational Lung Disorders. European Respiratory Monograph; 1999;4:158-177

44. Teschler H, Konietzo N, Schoenfeld B, Ramin C, Schraps T, Costabel U. Distribution of asbestos bodies in the human lung as determined by bronchoalveolar lavage. Am Rev Respir Dis 1993;147:1211-1215

45. Vathesatogkit P, Harkin TJ, Addrizo-Harris DJ, Bodkin M, Crane M, Rom WN. Clinical correlation of asbestos bodies in BAL fluid. Chest 2004;126:966-971

46. De Vuyst P, Dumortier P, Moulin E, et al. Guidelines for mineral fibre analysis in biological samples: report of the ERS Working Group. European Respiratory Society. Eur Respir J 1998;11:1416-1426

47. Romeo R, Scancarello G, Cassano P, Cioni F, Bacaloni A, Sartorelli P. Assessment of asbestos exposure via mineralogical analysis of bronchoalveolar lavage fluid. Med Lav 2004;95:17-31
48. De Vuyst P, Dumortier P, Moulin E, et al. Asbestos bodies in bronchoalveolar lavage reflect lung asbestos body concentration. Eur Respir J 1988;1:362-367

49. Sebastien P, Armstrong B, Monchaux G, et al. Asbestos bodies in bronchoalveolar lavage fluid and in lung parenchyma. Am Rev Respir Dis 1988;137:75-78

50. De Vuyst P, Dumortier P, Moulin E, et al. Diagnostic value of asbestos bodies in bronchoalveolar lavage fluid. Am Rev Respir Dis 1987;136:1219-1224

51. Roggli VL, Coin PG, MacIntyre NR, Bell DY. Asbestos content of bronchoalveolar lavage fluid: a comparison of light and scanning electron microscopic analysis. Acta Cytol 1994; 38:502-510

52. Dumortier P, Thimpont J, de Maertelaer V, De Vuyst P. Trends in asbestos body count in bronchoalveolar lavage fluid over two decades. Eur Respir J 2003;22:519-524

53. Rom WN, Weiden M, Garcia R, et al. Acute eosinophilia in a New York City firefighter exposed to World Trade Center dust. Am J Respir Crit Care Med 2002;166:797-800

54. Fireman E, Greif J, Schwarz Y, et al. Assessment of hazardous dust exposure by BAL and Induced Sputum. Chest 1999;115:1720-1728

55. Teschler H, Thompson AB, Dollenkamp R, Konietzo N, Costabel U. Relevance of asbestos bodies in sputum. Eur Respir J 1996;9:680-686

56. Fireman E, Lerman Y. Induced sputum in interstitial lung diseases. Curr Opin Pulm Med 2006;12:318-322

57. Sulotto F, Capellaro E, Chiesa A, et al. Relationship between asbestos bodies in sputum and the number of specimens. Scand J Work Environ Health 1997;23:48-53

58. Capellaro E, Chiesa A, Villari S, et al. Asbestos bodies in bronchoalveolar lavage fluid and sputum. Med Lav 1997;88: 99-107

59. Fireman E, Greif J, Schwarz Y, et al. Assessment of hazardous dust exposure by BAL and induced sputum. Chest 1999;115:1720-1728

60. Newman LS, Mroz MM, Balkisson R, Maier LA. Beryllium sensitization progresses to chronic beryllium disease: a longitudinal study of disease risk. Am J Respir Crit Care Med 2005;171:54-60

61. Sawyer RT, Parsons CE, Fontenot AP, et al. Berylliuminduced tumor necrosis factor- $\alpha$ production by $\mathrm{CD} 4+\mathrm{T}$ cells is mediated by HLA-DP. Am J Respir Cell Mol Biol 2004;31:122-130

62. Rossman MD, Kern JA, Elias JA, et al. Proliferative response of bronchoalveolar lymphocytes to beryllium. Ann Intern Med 1988;108:687-693

63. Zhang H, Li Q, Yao R, Guo N. Experimental studies on the therapeutic effects of lung lavage with large volume of saline on silicosis. Wei Sheng Yan Jiu 1997;26:77-79 